\title{
Heterogeneous Catalysis of African Pear Seed Oil and Modelling of Some Thermo-Physical Properties of its Biodiesel
}

Callistus Nonso Ude ( $\nabla$ callyjoe4real@gmail.com )

Michael Okpara University of Agriculture

Dominic 0. Onukwuli

Nnamdi Azikiwe University

Faith C. Okey-Onyesolu

Nnamdi Azikiwe University

Patrick C. Nnaji

Michael Okpara University of Agriculture

Chukwunonso C. Okoye

Nnamdi Azikiwe University

Chidebe C. Uwaleke

AE-FUNAl: Alex Ekwueme Federal University Ndufu-Alike

\section{Research Article}

Keywords: Heterogeneous Catalysis, Pear Seed Oil, Thermo-Physical Properties, Biodiesel

Posted Date: July 29th, 2021

DOI: https://doi.org/10.21203/rs.3.rs-746331/v1

License: () (1) This work is licensed under a Creative Commons Attribution 4.0 International License.

Read Full License 


\section{Heterogeneous catalysis of African Pear Seed Oil and Modelling of Some Thermo-Physical Properties of its}

\section{Biodiesel}

Ude Callistus N.*, ${ }^{,}$, Onukwuli Dominic O. ${ }^{2}$, Okey-Onyesolu Faith C. ${ }^{3}$, Nnaji Patrick C. ${ }^{4}$, Okoye Chukwunonso C. ${ }^{5}$, Uwaleke Chidebe C. ${ }^{6}$

${ }^{1,4}$ Department of Chemical Engineering, Michael Okpara University of Agriculture, Umudike, Umuahia, Abia State, Nigeria.

${ }^{2,3,5}$ Department of Chemical Engineering, Nnamdi Azikiwe University (NAU), Awka, Nigeria. ${ }^{6}$ Department of Science Education, Alex Ekwueme Federal University, Ndufu-Alike, Ebonyi State, Nigeria.

(*callyjoe4real@gmail.com, +2348039353284 )

\section{Abstract}

The heterogeneous catalysis of African pear seed oil (APO) and modelling of some thermo-physical properties of the biodiesel was carried out. The oil was extracted with petroleum ether solvent and characterized with Association of Analytical Chemist (AOAC). The catalysts were synthesized by thermal, acid and alkaline activation of clay. The catalysts were characterized and used to transesterify the APO. The biodiesel produced were characterized using American Society for Testing Materials ASTM D6571 and some the thermo-physical properties such as density, kinematic viscosity and cetane number were modelled using multilinear regression analysis of Polymath version 5.0. The 52\% yield of oil from the African pear seeds using the petroleum ether was comparable with yields obtained from other nonedible seeds. The transesterification of the oil was significantly affected by increase in process variables but the yield of methyl ester decreased beyond $3 \mathrm{~h}$ reaction time, $3 \mathrm{wt} \%$ catalyst concentration, 10:1 methanol/oil molar ratio, $60{ }^{\circ} \mathrm{C}$ reaction temperature and $300 \mathrm{rpm}$ agitation speed. The physicochemical properties of the biodiesel produced meet the ASTM standard and were within the acceptable limits. The biodiesel produced via transesterification of APO using thermally, acid and alkaline activated catalyst have similar properties and can be blended to form a homogeneous fuel. The coefficients of determination are close to 1 while the root mean square value is less than 0.2. This shows that the multilinear regression can model the thermo-physical properties of the biodiesel.

\section{Introduction}

Energy stimulates socio-economic development. The growth world's economy is highly influenced by changes in climate, incessant increase in fuel price, and continuous depletion of petroleum reserves. In order to secure energy and maintain economic development, it is pertinent to focus attention on biofuels as alternative sources of energy (Oh et al. 2002; Uma and Kim 2009; Ude and Onukwuli 2019a). Biodiesel is renewable, sustainable, biodegradable, and emits low greenhouse gases (Sharma and Singh 2009; Lee et al. 2010; Ofoefule et al. 2013). Moreover, it contains about 11-15\% oxygen which enhances combustion process in compression ignition engines and reduces the emission of gaseous pollutants, soot and fine particles (Lee et al. 2011; Kim et al. 2007). Hence, it is a potential substitute to petro-diesel (Saeid et al. 2008; Szulczyk and McCarl 2010; Ofoefule et al. 2013).

Biodiesel fuel is mostly produced via transesterification of refined or waste vegetable oil and nonedible oils using alkaline catalysts (Chhetri and Watts 2008; Bai et al. 2011). The nature of catalyst greatly affects the transesterification reaction and various kinds of catalysts have been investigated for production of biodiesel. The catalysts are classified as homogeneous and heterogeneous catalysts. The conventional homogeneous catalysts like sodium hydroxide, potassium hydroxide, sodium methanoate, and potassium methanoate are mostly used in biodiesel production (Sharma et al. 2008). Their good catalytic activity and ability to speed up the transesterification reaction under moderate conditions has led to their choice (Hideki et al. 2001). However, they have some drawbacks such as difficult to recover 
and generation of waste water leading to downstream waste treatment which invariably increase the biodiesel production cost. They are limited to oils with low value of FFA to prevent soap generation and catalyst consumption. They react with water in the oil. Nevertheless, the use of heterogeneous catalyst can overcome these challenges and eliminate the additional cost that may be incurred during further processing of biodiesel (Ude and Onukwuli 2019a). Hence, heterogeneous catalyst has gained much attention in the recent time.

Numerous materials have been studied as heterogeneous catalysts for transesterification of vegetable oils and fats. They include animal bone, eggshell, periwinkle shell and clay (Ude and Onukwuli 2019a). Among these clay is most abundant. It is a solid acid catalyst which exhibits both Lewis and Bronsted acid behaviour in their natural and ionexchanged form (Ude and Onukwuli 2019a; Clark 2004). It can catalyse transesterification in thermally activated form (Ude and Onukwuli 2019b), acid activated form (Onukwuli and Ude 2018) and alkaline activated form (Ude and Onukwuli 2019a). It is pertinent to predict some vital thermo-physical properties of biodiesel produced using activated clay in order to widen its application in biodiesel technology. Thermo-physical properties of biodiesel/diesel blends are very relevant for spray characterises, combustion, and emission characteristic in internal combustion engines (Olusegun et al. 2019; Cheng et al. 2013; Sanjid et al. 2015). There are few or limited report on prediction of thermophysical properties of biodiesel produced from transesterification of edible and nonedible seed oils catalysed by activated clay. The study aimed at heterogeneous catalysis of African pear seed oil by activated clay and prediction of some thermo-physical properties of the biodiesel.

\section{Materials and Methods}

\subsection{Materials}

The African pear seed was purchased from Nkwo Ezeagu Market, Obinofia Ndi-uno, Enugu State, Nigeria. The reagents, petroleum ether and other solvents were bought from Gerald Chemicals Ogbete Main market, Enugu, Enugu State, Nigeria. They were of analytical grade. Clay was collected from Agbaja, Ebonyi State, Nigeria.

\subsection{Methods}

\subsubsection{Extraction of Oil and its characterization}

The procedure adopted by Ude and Onukwuli (2018) was employed with little modification. The seeds were dried in an oven at temperature of $120^{\circ} \mathrm{C}$ for 3 hours, deshelled and grounded to powder. $120 \mathrm{~g}$ of the sample was mixed with petroleum ether with solvent/solute ratio of $2 \mathrm{ml} / \mathrm{g}$ and stirred with a constant speed of $150 \mathrm{rpm}$ at a temperature of 40 ${ }^{\circ} \mathrm{C}$ for 1 hour. It was then transferred to a rotary evaporated to recover the solvent. The yield of the raw oil extracted was determined using Equation (1).

$Y=\frac{m_{A P O}}{m_{A P S}} \times 100$

Where $\mathrm{Y}=$ yield of oil $(\%), m_{A P O}=$ mass of African pear seed oil extracted $(\mathrm{g}), m_{A P S}=$ mass of African pear seed (g).

The oil extracted was analyzed using Association of Analytical Chemist (AOAC, 1990) for physical and chemical properties. 


\subsubsection{Preparation of catalyst}

The heterogeneous catalyst used is clay and was synthesized using the method employed by Manuit and Statit (2007). The clay was immersed in a solution of $\mathrm{H}_{2} \mathrm{O}_{2}(30 \%)$ at $30{ }^{\circ} \mathrm{C}$ for $24 \mathrm{~h}$ to purify it in the ratio of $4: 8 \mathrm{wt} / \mathrm{wt}$. The excess hydrogen peroxide was removed by heating the mixture in a boiling water bath. Distilled water was then added in a ratio of 1:4 wt/wt and allowed to settle. The clay was filtered off and dried in an oven at a temperature of $110{ }^{\circ} \mathrm{C}$ and pulverized and sieved with 80/100mesh.

The dried clay was modified with thermal, acid and alkaline activation to improve its catalytic activity adopting the methods of Ude and Onukwuli (2019b, a) and Onukwuli and Ude (2018) respectively.

\subsubsection{Characterization of the synthesized catalysts}

The composition of metals, functional group, morphology, classification and surface area of the raw and activated clay were determined with X-ray fluorescence (ARL 9400XP) spectrometer, Fourier- transform infra-red spectrometer (BUCK model 500 M), scanning electron microscope (Carl Zeiss Sigma Field Emission), X-ray Diffractometer (model XRD-7000) and Brunauer-Emmett-Teller (BET) respectively.

\subsubsection{Transesterification reaction}

The biodiesel was produced by thermal, acid and alkaline activated clay catalysed transesterification reaction between African pear seed oil (APO) and methanol.

$50 \mathrm{~kg}$ of APO was measured transferred into a-three-neck flat bottom flask fitted with thermometer and reflux condenser. A certain quantity of the catalysts was weighed and mixed with methanol. The mixture was then added to the flask and placed on a hot magnetic stirrer. The reaction was maintained at a constant temperature with a particular speed for defined period of time. When the reaction time was attained, the reaction was stopped and the mixture was allowed to cool. The biodiesel was separated from the glycerol using separation funnel. The biodiesel yield was calculated using equation (2).

$$
Y=\frac{\text { weight of biodiesel }}{\text { weight of oil used }} \times 100
$$

The method was repeated by varying some of the transesterification reaction parameters such as such as; time $(1-5$ h), catalyst weight $(1-5 \mathrm{wt} \%)$, temperature $\left(40-80^{\circ} \mathrm{C}\right)$, alcohol/oil molar ratio $(6: 1-14: 1)$ and agitation speed $(100$ $-500 \mathrm{rpm}$ ) for all the catalysts.

\subsubsection{Modelling of thermo-physical properties of biodiesel}

Linear and multiple linear regressions (MLR) were employed to model the thermo-physical properties of biodiesel produced in this study. MLR is a multivariate statistical technique for examining the linear correlation between two or more independent variable and a single dependent variable. Linear dependence was developed to model physical properties of biodiesel produced from African pear oil (APO). Linear regression was carried out to fit the following linear equations with unknown coefficients.

For density 
$\rho=a_{0}+a_{1} x$

Where $\rho=$ density, $\mathrm{x}=$ fraction of biodiesel

For viscosity

$$
\begin{aligned}
& \gamma=a_{0}+a_{1} x \\
& \gamma=a_{0}+a_{1} T
\end{aligned}
$$

Where $\gamma=$ kinematics viscosity, $\mathrm{x}=$ fraction of biodiesel, $\mathrm{T}=$ temperature in Kelvin

For cetane number

$\mathrm{CN}=a_{0}+a_{1} \rho+a_{2} \gamma+a_{3} F P+a_{4} L H V$

Where $\mathrm{CN}$ is the cetane number, FP = flash point, LHV = lower heating value.

To predict the thermo-physical properties of biodiesel from blends and temperature, linear regression LR and multiple linear regression, MLR models were developed using polymath version 6.0 software by processing the full experimental data obtained in this work. The developed models performances were justified by comparing their statistical values such as; root-mean-square error (RMSE) and coefficients of determination, (R-square).

\section{Results and Discussion}

\subsection{Oil extraction}

The yield of oil obtained is 52\%. This is very close to $53.1 \%$ obtained by Onukwuli and Ude (2018) when they used n-hexane to extract oil from African pear seed. It is greater than the ones reported for some nonedible seed oil like $36.86 \%$ yield reported by Okonkwo and Mukhtar (2013), 47\% seed oil of almond (Ogunsuyi and Daramola 2013) and $16 \%$ seed oil of tigernut (Ofoefule et al. 2013). It was also relatively close to that of soybeans $65 \%$ and cottonseed $60 \%$ (Rashid et al. 2009).

\subsection{Characterization of the extracted oil}

The physicochemical properties of the raw oil of APO are presented in Table 1. The properties of the APO is related with that of Pongamia pinnata (Rahman et al., 2011), Jatropha curcas (Adebayo et al. 2011), Madhuca indica (Azam et al. 2005).

The acid number and free fatty acid values of the oil is moderate but above $1 \%$. The density and the viscosity of the oil are high and will not atomize easily in internal combustion engine, therefore it cannot be directly used in an engine. The oil has low value of pour point indicating that it is durable while the high flash point of the oil indicates that it is not flammable. The oxidation stability of the oil is high which makes it a suitable feedstock for biodiesel production. The iodine value of APO is less than $100 \mathrm{gI}_{2} / 100 \mathrm{~g}$ signifying that the oil does not dry on exposure to atmosphere/sunlight. The high saponification value shows that it can readily form of soap with homogeneous catalyst. These indicate that the APO requires pre-treatment but the use of heterogeneous process will bypass it.

Table 1: Physio-chemical properties of African pear seed oil

S/N Physio-chemical properties $\quad$ APO




\begin{tabular}{lll}
\hline 1 & Density $(\mathrm{g} / \mathrm{ml})$ & 0.925 \\
2 & Acid value $(\mathrm{mgKOHg})$ & 5.51 \\
3 & FFA $(\%)$ & 2.76 \\
4 & Spanofication value $(\mathrm{mgKOH} / \mathrm{g})$ & 120 \\
5 & Iodine value $\left(\mathrm{gI}_{2} / 100 \mathrm{~g}\right)$ & 23.54 \\
6 & $\mathrm{KV}$ at $40^{\circ} \mathrm{C}\left(\mathrm{mm}^{2} / \mathrm{s}\right)$ & 8.10 \\
7 & PV & 5.2 \\
8 & FP $\left({ }^{\circ} \mathrm{C}\right)$ & 231 \\
9 & $\mathrm{CP}\left({ }^{\circ} \mathrm{C}\right)$ & -3 \\
10 & Pour point & 12 \\
11 & Moisture content $(\%)$ & 7.2 \\
12 & RI & 1.46 \\
13 & Oxidation stability $11^{\circ} \mathrm{C}($ Hour $)$ & 5 \\
14 & Molecular weight & 869.1 \\
\hline $\mathrm{RI}=$ refractive index, PV = peroxide value, FP = flash point, cloud point, $\mathrm{KV}=$ kinematics viscosity.
\end{tabular}

\subsection{Characterization of the synthesized catalysts}

\subsubsection{Physiochemical properties of the catalyst}

Table 2 depicts the physiochemical properties of the raw and modified clay catalysts. It was discovered that the modification enhanced the properties of the clay with acid activated clay catalyst (AAC) having more surface area. The size of the pore of the raw clay increased after different mode of modification and this could be attributed to widening of pores by the modification. Also, the pore volume increased after activation indicating that more pores where opened.

Table 2: Physiochemical properties catalysts

\begin{tabular}{lllll}
\hline Property & Raw clay & $\begin{array}{l}\text { Thermally activated } \\
\text { clay (TAC) }\end{array}$ & $\begin{array}{l}\text { Base activated } \\
\text { clay (BAC) }\end{array}$ & AAC \\
\hline Surface area $\left(\mathrm{m}^{2} / \mathrm{g}\right)$ & 287.1 & 487.6 & 436.4 & 526.2 \\
Pore size $(\mathrm{nm})$ & 2.647 & 4.523 & 2.864 & 5.901 \\
$\begin{array}{l}\text { Total pore volume } \\
\left(\mathrm{cm}^{3} / \mathrm{g}\right)\end{array}$ & 13.67 & 25.3 & 17.33 & 26.0 \\
\hline
\end{tabular}

\subsubsection{Elemental test of the catalysts}


Table 3 depicts the composition of oxides of some elements present in the raw, thermally activated, acid activated and base/alkaline activated clay. The major elements domicile in the clay are $\mathrm{Al}, \mathrm{Si}, \mathrm{Fe}$ and $\mathrm{Ti}$. The main metallic oxide present are oxides of magnesium, aluminium, silicon, potassium, calcium, titanium, chromium, manganese, iron, zinc and strontium and they constitute heterogeneous catalysts (Sani et al. 2014). The raw clay has reasonable compositions of $\mathrm{Al}_{2} \mathrm{O}_{3}, \mathrm{SiO}_{2}$, and $\mathrm{Fe}_{2} \mathrm{O}_{3}$ but only the amount of $\mathrm{SiO}_{2}$ and $\mathrm{Al}_{2} \mathrm{O}_{3}$ increased after the activation. Reduction of $\mathrm{Fe}_{2} \mathrm{O}_{3}$ is high in acid and alkaline activated clay and is due to leaching. These suggests that the acid and base/alkaline activated clay could be categorized as Brønsted and Lewis acids. Their catalytic properties depend on the positive ions bonded to the negative ions of alumina-silicate. Consequently, the strength of the sites was improved by the activation (Sani et al., 2014).

Table 3: Elemental test of the catalysts

\begin{tabular}{lllll}
\hline Elements & Raw clay & $\begin{array}{l}\text { Chermally activated } \\
\text { clay }\end{array}$ & Acid activated clay & $\begin{array}{l}\text { Base/alkaline } \\
\text { activated clay }\end{array}$ \\
$\mathrm{Na}_{2} \mathrm{O}$ & 0.000 & 0.000 & 0.000 & 0.163 \\
$\mathrm{MgO}$ & 0.323 & 0.386 & 0.326 & 0.235 \\
$\mathrm{Al}_{2} \mathrm{O}_{3}$ & 23.132 & 23.565 & 27.642 & 25.743 \\
$\mathrm{SiO}_{2}$ & 57.115 & 57.403 & 64.556 & 67.197 \\
$\mathrm{P}_{2} \mathrm{O}_{5}$ & 0.310 & 0.311 & 1.118 & 0.286 \\
$\mathrm{SO}_{3}$ & 0.246 & 0.269 & 0.303 & 0.343 \\
$\mathrm{Cl}$ & 0.0175 & 0.019 & 0.010 & 0.017 \\
$\mathrm{~K}_{2} \mathrm{O}$ & 0.081 & 0.089 & 0.122 & 0.114 \\
$\mathrm{CaO}$ & 0.767 & 0.773 & 0.024 & 0.020 \\
$\mathrm{TiO}_{2}$ & 4.871 & 4.098 & 3.606 & 3.644 \\
$\mathrm{Cr}_{2} \mathrm{O}_{3}$ & 0.029 & 0.030 & 0.029 & 0.028 \\
$\mathrm{Mn}_{2} \mathrm{O}_{3}$ & 0.056 & 0.052 & 0.013 & 0.014 \\
$\mathrm{Fe}_{2} \mathrm{O}_{3}$ & 12.628 & 11.963 & 2.230 & 2.178 \\
$\mathrm{ZnO}$ & 0.023 & 0.021 & 0.003 & 0.002 \\
$\mathrm{SrO}$ & 0.025 & 0.023 & & 0.019 \\
\hline
\end{tabular}

\subsubsection{Determination of functional groups present in the catalysts}


The functional groups of the catalysts were determined and presented in Table 4. The data shown in the table indicate that the catalysts possess similar functional groups such as organo silicon-oxygen bond, carbon-chlorine of chloro alkane compounds, carbon-hydrogen stretch of aromatic bend, carbon-hydrogen stretch of vinyl, Organic silicone Si$\mathrm{O}-\mathrm{C}, \mathrm{Si}-\mathrm{O}$, carbon-carbon double bond, hydroxyl stretch of primary alkanol, hydroxyl-aluminate, Al-OH-Mg and Al-OH-O-Si vibrations. Comparatively, the changes in the intensities of the peaks for the raw clay and the modified clays were insignificant. This indicate that the modification did not immensely change the structure of the clay. The presence of cyanide ion in the raw clay contributes to its low catalytic activity, hence suggests the need for modification.

Table 4: Functional groups test of the catalysts

\begin{tabular}{|c|c|c|c|c|c|}
\hline \multicolumn{5}{|c|}{ Wave number $\left(\mathrm{cm}^{-1}\right)$ of catalyst } & \multirow[t]{2}{*}{ Functional groups } \\
\hline $\mathrm{S} / \mathrm{N}$ & Raw clay & $\begin{array}{l}\text { Thermally } \\
\text { activated clay } \\
\text { (TAC) }\end{array}$ & $\begin{array}{l}\text { Acid activated } \\
\text { clay (AAC) }\end{array}$ & $\begin{array}{l}\text { Base activated } \\
\text { clay (BAC) }\end{array}$ & \\
\hline 1 & 678.4 & 678.4 & 678.4 & 685.8 & Si-O-Si deformation \\
\hline 2 & 751.8 & 749.2 & 751.8 & - & C-Cl, Chloro alkane compound \\
\hline 3 & 797.6 & 797.7 & 797.7 & 779.0 & C-Cl, Chloro alkane compound \\
\hline 4 & 908.5 & 908.5 & 908.5 & 908.5 & $\begin{array}{l}\mathrm{C}-\mathrm{H} \text { from Aromatic compound, } \\
\text { hydroxide aluminate }\end{array}$ \\
\hline 5 & 997.8 & 997.8 & 997.8 & 997.8 & $\begin{array}{l}\text { Vinyl C-H out-of-plane bend, } \\
\text { Al-OH-Mg }\end{array}$ \\
\hline 6 & 1117.5 & 1118.2 & 1114.5 & 1114.5 & Si-O-C, Si-O \\
\hline 7 & - & - & 1640.0 & - & Ketone \\
\hline 8 & 2010.1 & - & - & - & Cyanide ion \\
\hline 9 & 3651.6 & 3651.8 & 3652.1 & 3652.1 & $\begin{array}{l}\mathrm{C}=\mathrm{C} \text {, primary alkanol }-\mathrm{OH} \\
\text { stretch }\end{array}$ \\
\hline 10 & 3692.7 & 3693.8 & 3693.8 & 3652.8 & $\begin{array}{l}\mathrm{C}=\mathrm{C} \text {, primary alcohol }-\mathrm{OH} \\
\text { stretch }\end{array}$ \\
\hline
\end{tabular}




\subsubsection{Morphological analysis of the clay catalysts}

Scanning electron microscopes (SEM) was used to determine the morphologies of the raw and activated catalysts and shown in Figures 1(a-d) respectively. The figures showed that the number of pores and pore size increased after activation. It is observed in Figure 1c that acid activated clay has more pores which contributes to its high surface area as presented in Table 2 .

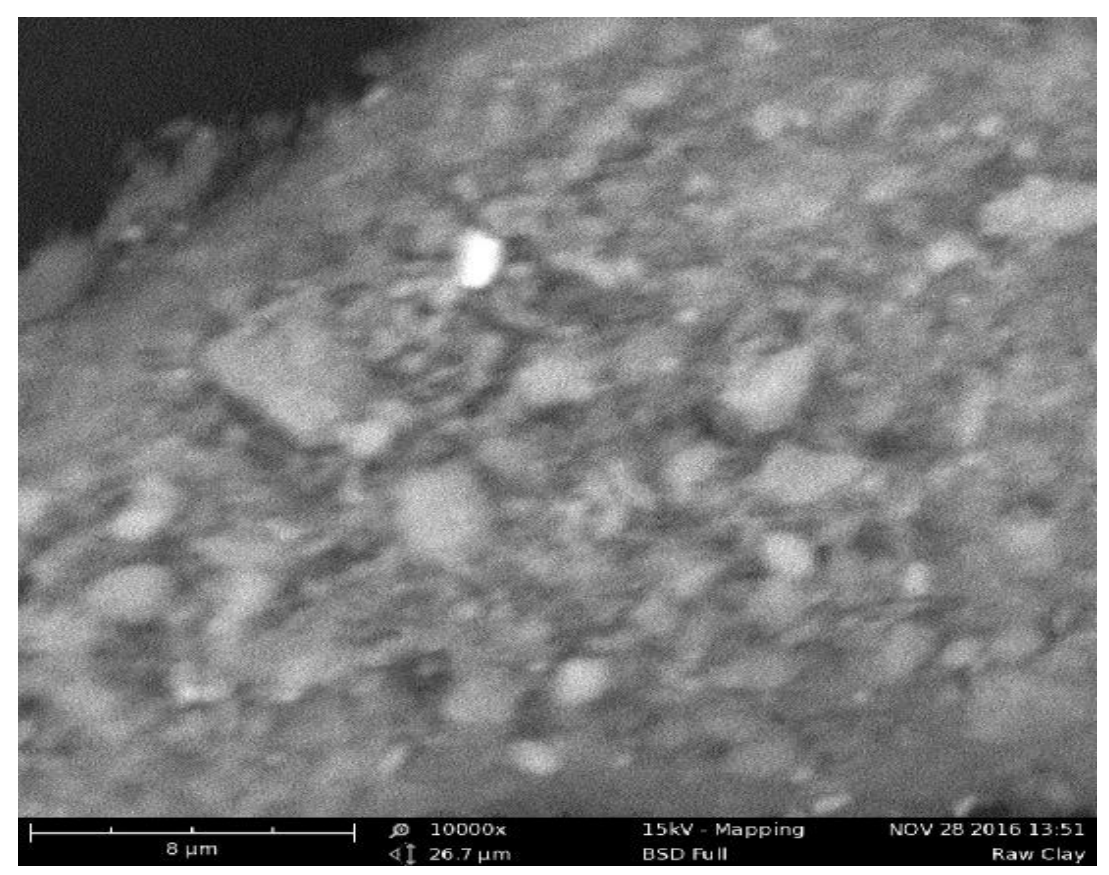

Fig. 1a Micrograph of raw clay 


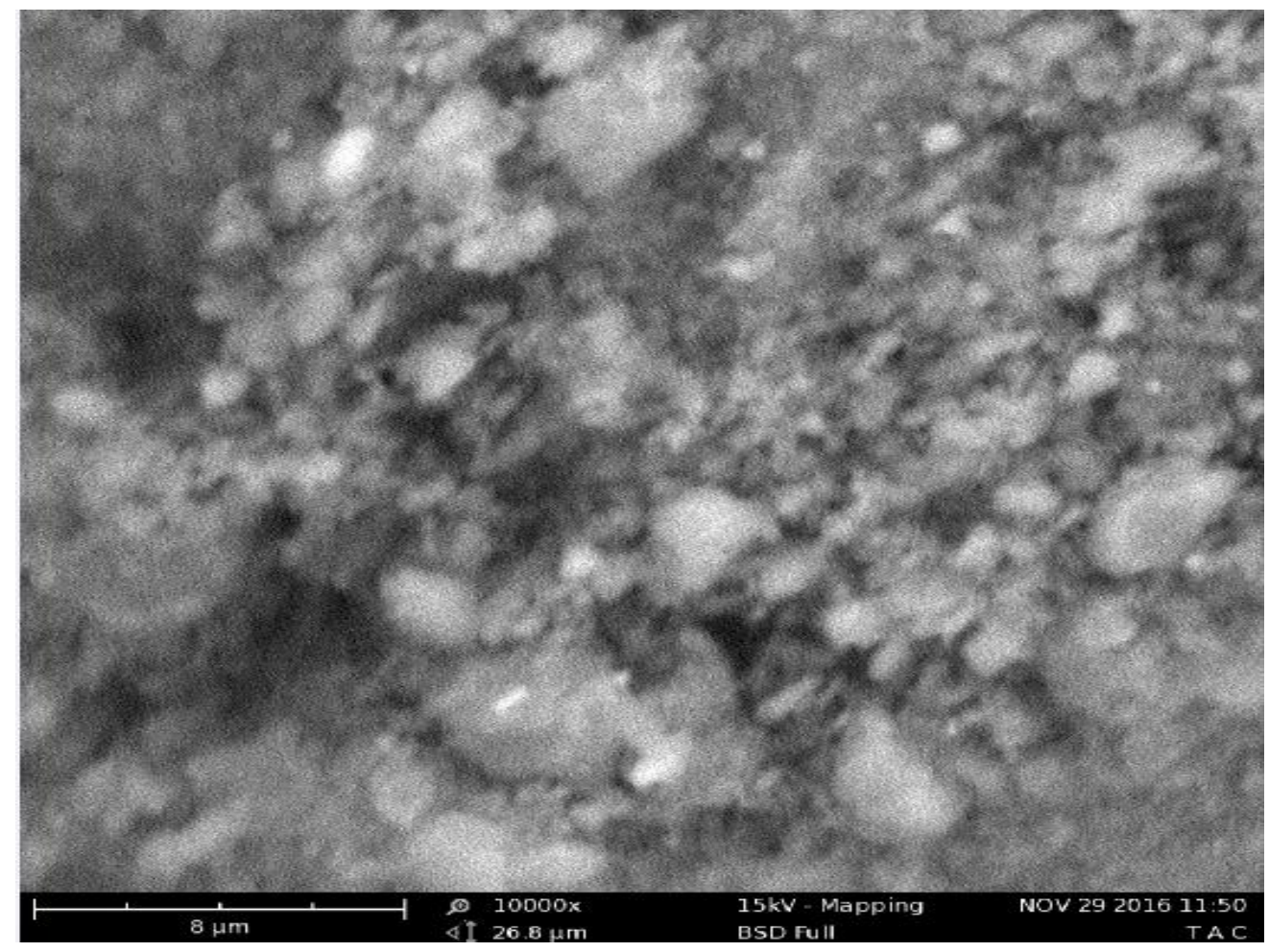

Fig. 1b Micrograph of thermally activated clay

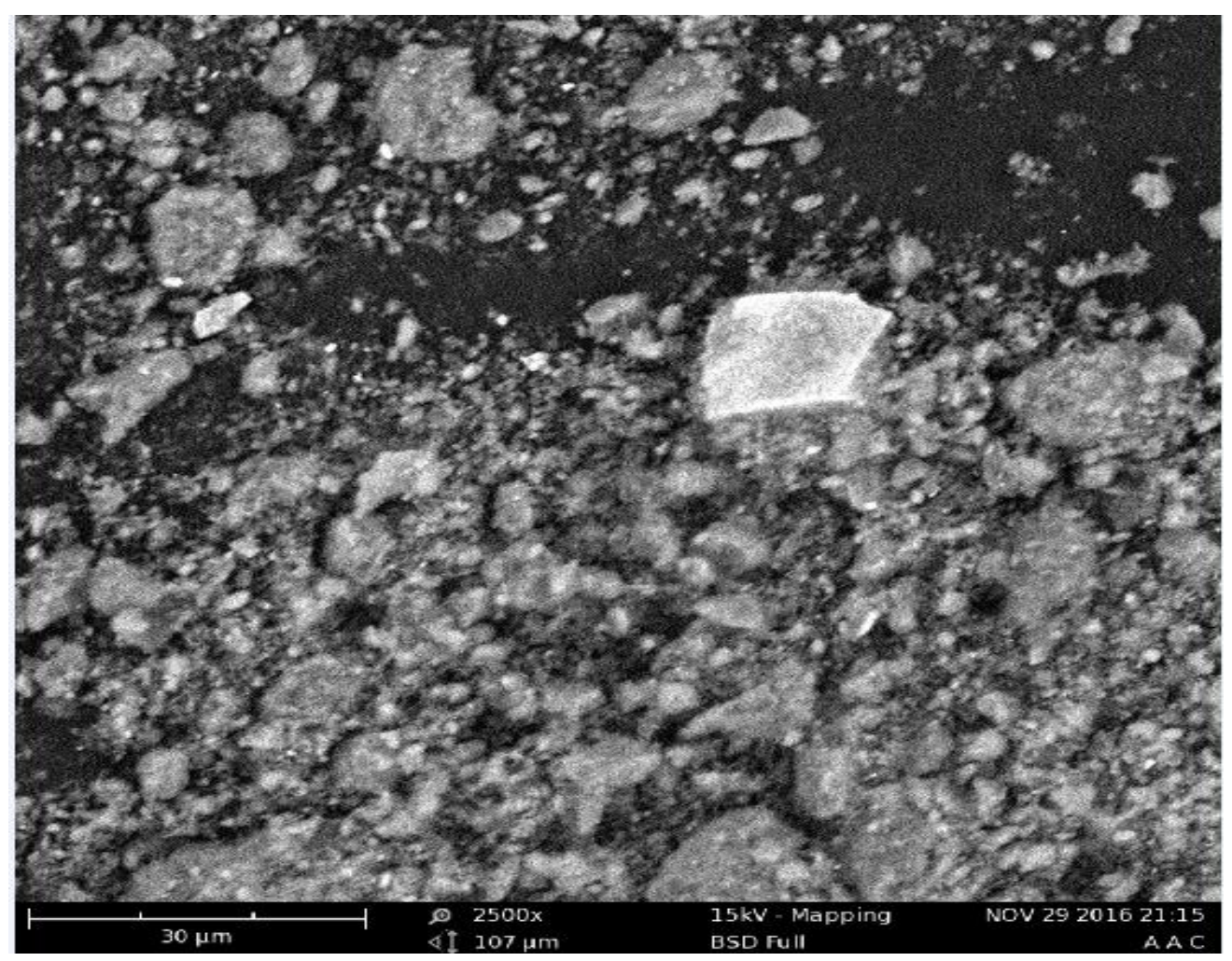

Fig. 1c Micrograph of acid activated clay 


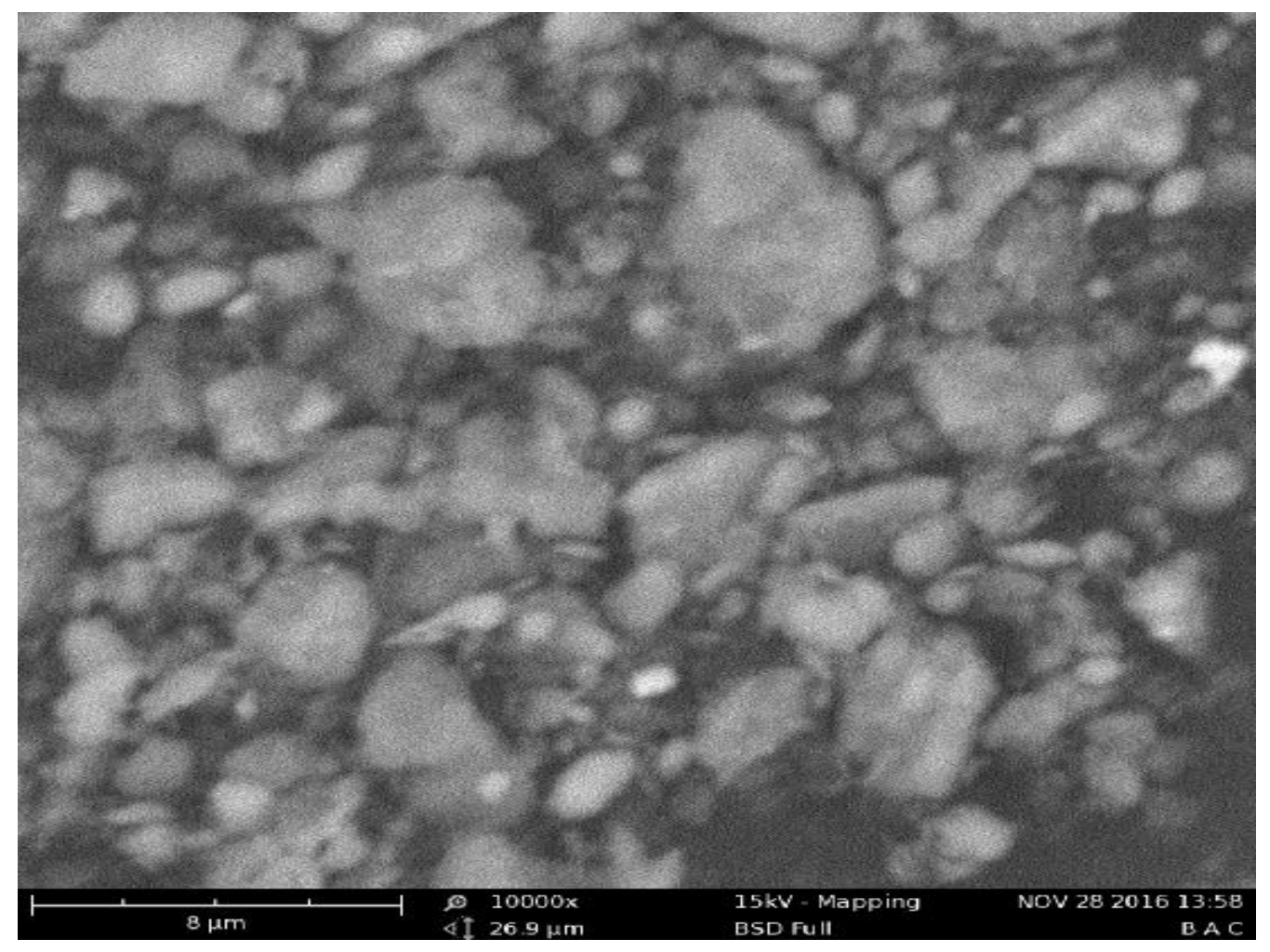

Fig. 1d Micrograph of base/alkaline activated clay

\subsubsection{X-ray diffraction analysis of the catalysts}

Figures 2 (a-d) depict diffractograms of the natural clay, thermal, acid and alkaline modified clays. Figure 2a shows that the clay belongs to kaolinite group confirming the presence of Alumina and silica and contains quartz which is a residual clay indicating that the clay is from the place of origin. It is observed that the activation of the clay by thermal, acid and alkaline methods modified the clay composition. Figure $2 b$ shows that thermal activation introduced phengite, acid activation introduced muscovite (Figure 2c) while alkaline activation introduced illite (Figure 2d) and this may be attributed to presence of sodium metal from the alkaline used. 


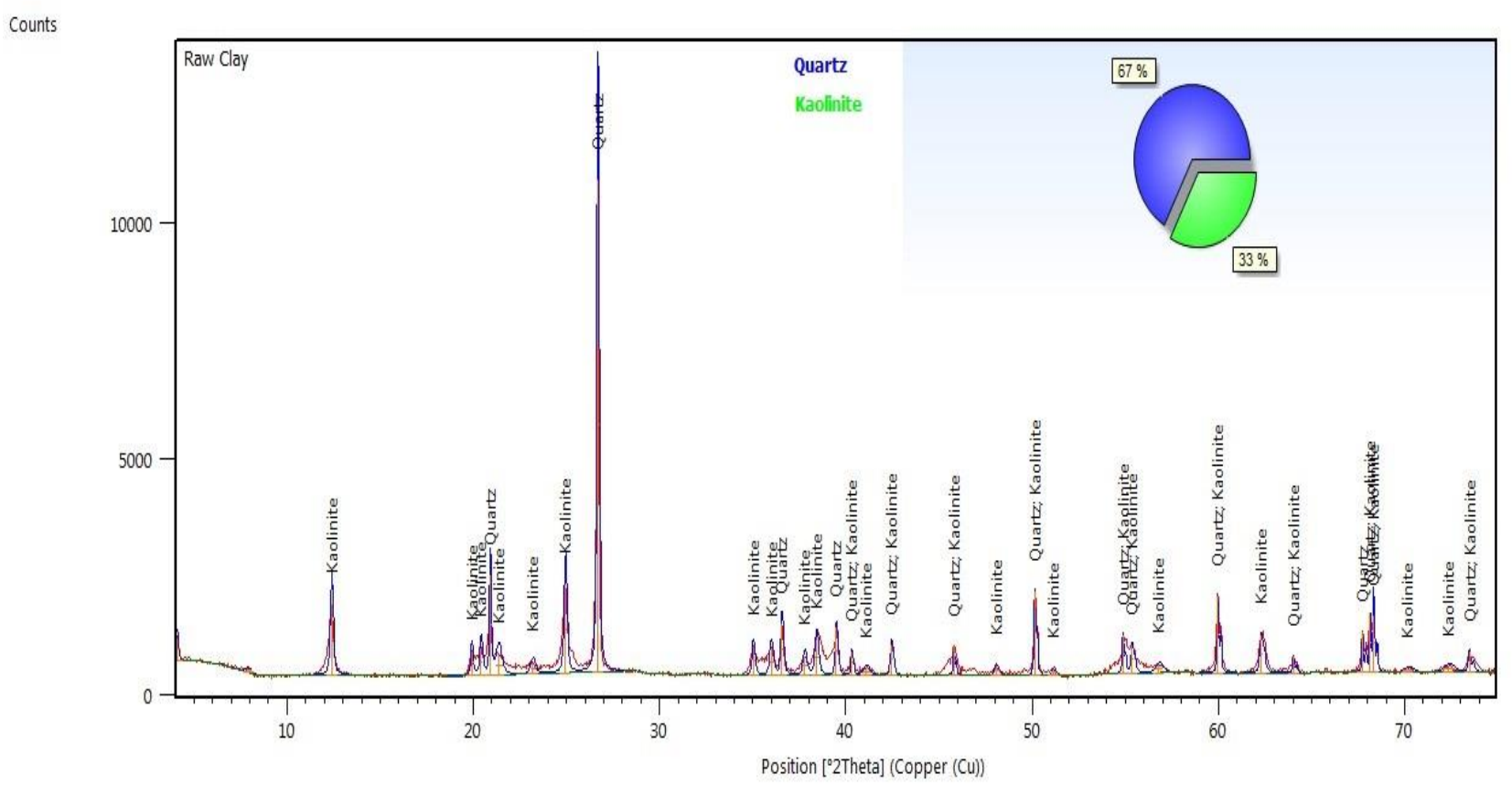

Fig. 2a XRD of raw clay

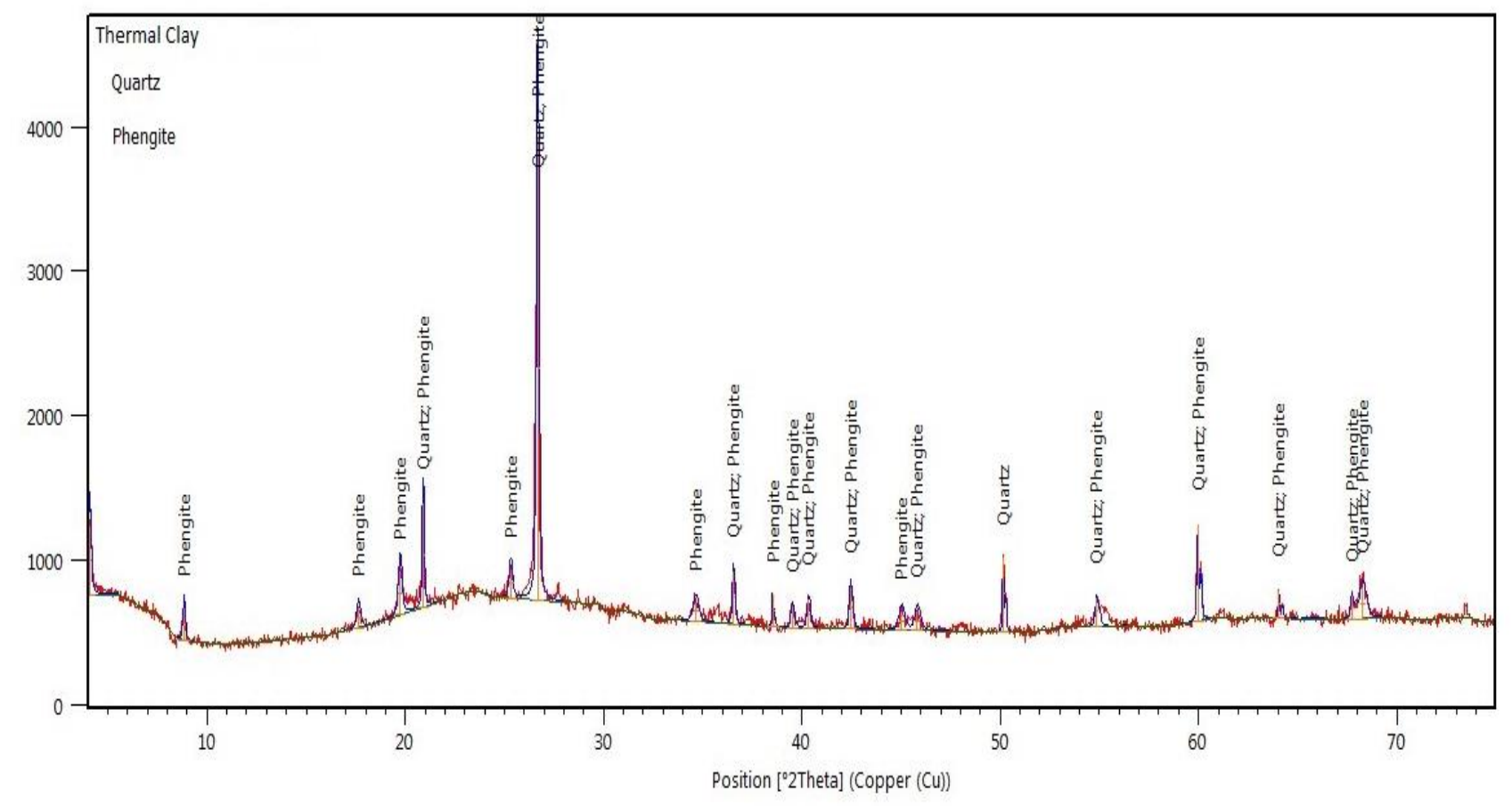

Fig. 2b XRD of thermally activated clay 


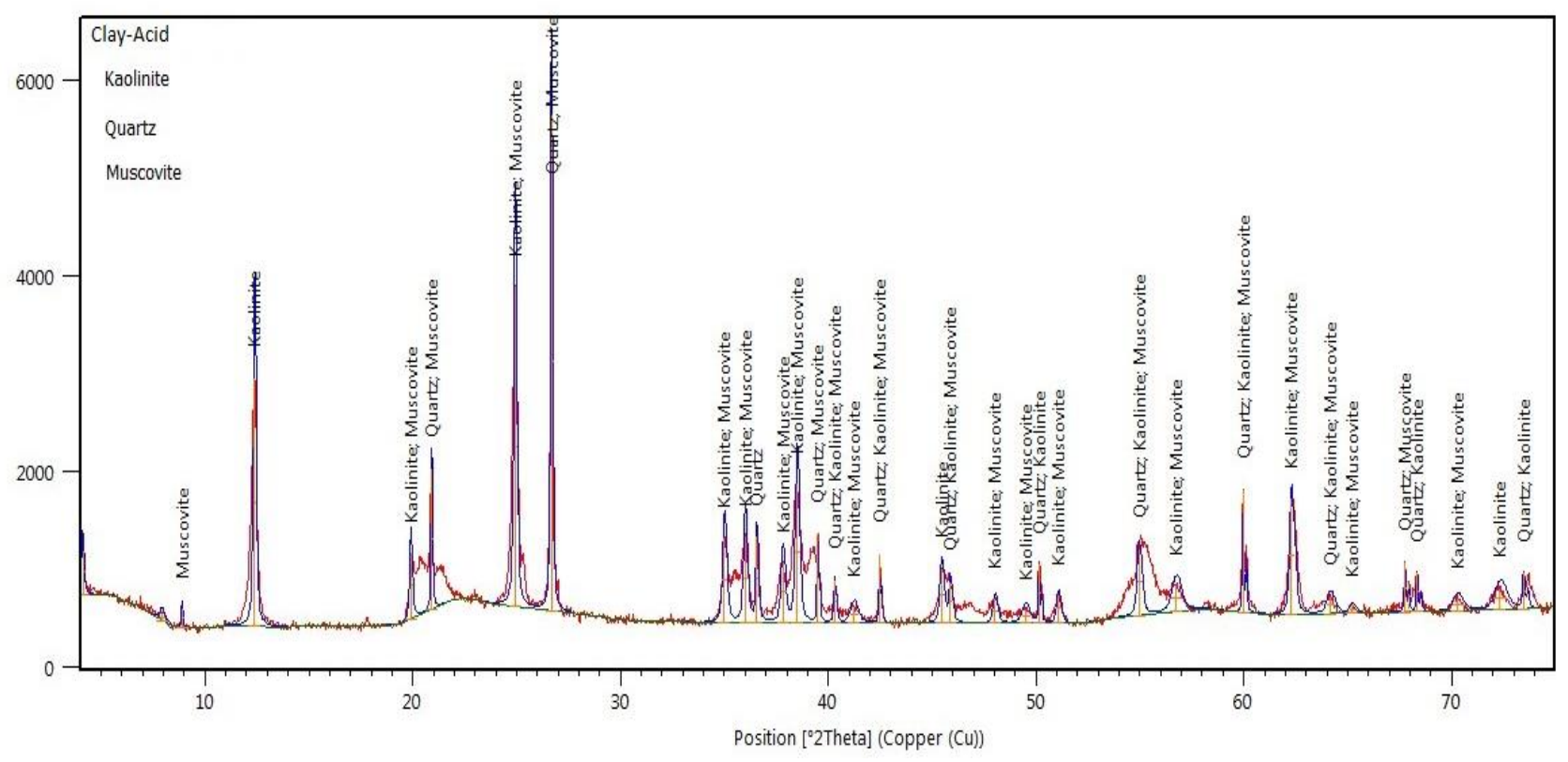

Fig. 2c XRD of acid activated clay catalyst

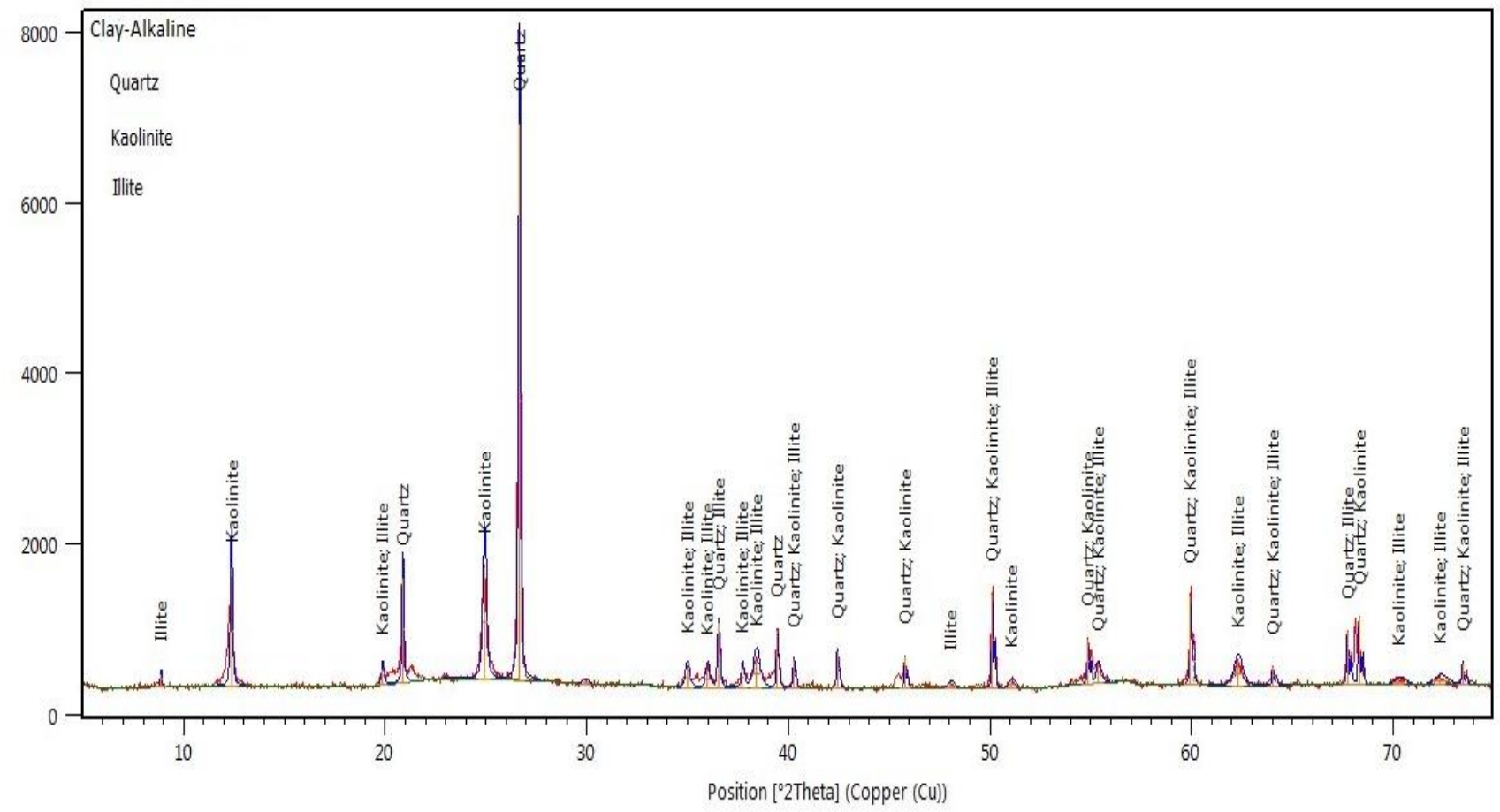

Fig. 2d XRD of base/alkaline activated clay catalysts.

\subsection{Influence of Process Variable on Biodiesel Yield}

\subsubsection{Influence of time on the yield}

The percentage yield of biodiesel increased as time increases. The influence of time from $1 \mathrm{~h}$ to $5 \mathrm{~h}$ on the biodiesel yield using raw clay, thermal, acid and base activated clay were investigated and shown in Figure 3. The yield increases 
slowly due to diffusion of the reactant species into active site and maximum yield was observed at $3 \mathrm{~h}$ but reduced above it. The reduction may be due to esters lost during reversible reaction. The yield obtained by thermally, acid and base/alkaline activated clay was found to be greater than the yield by raw clay and this could be attributed to the activation.

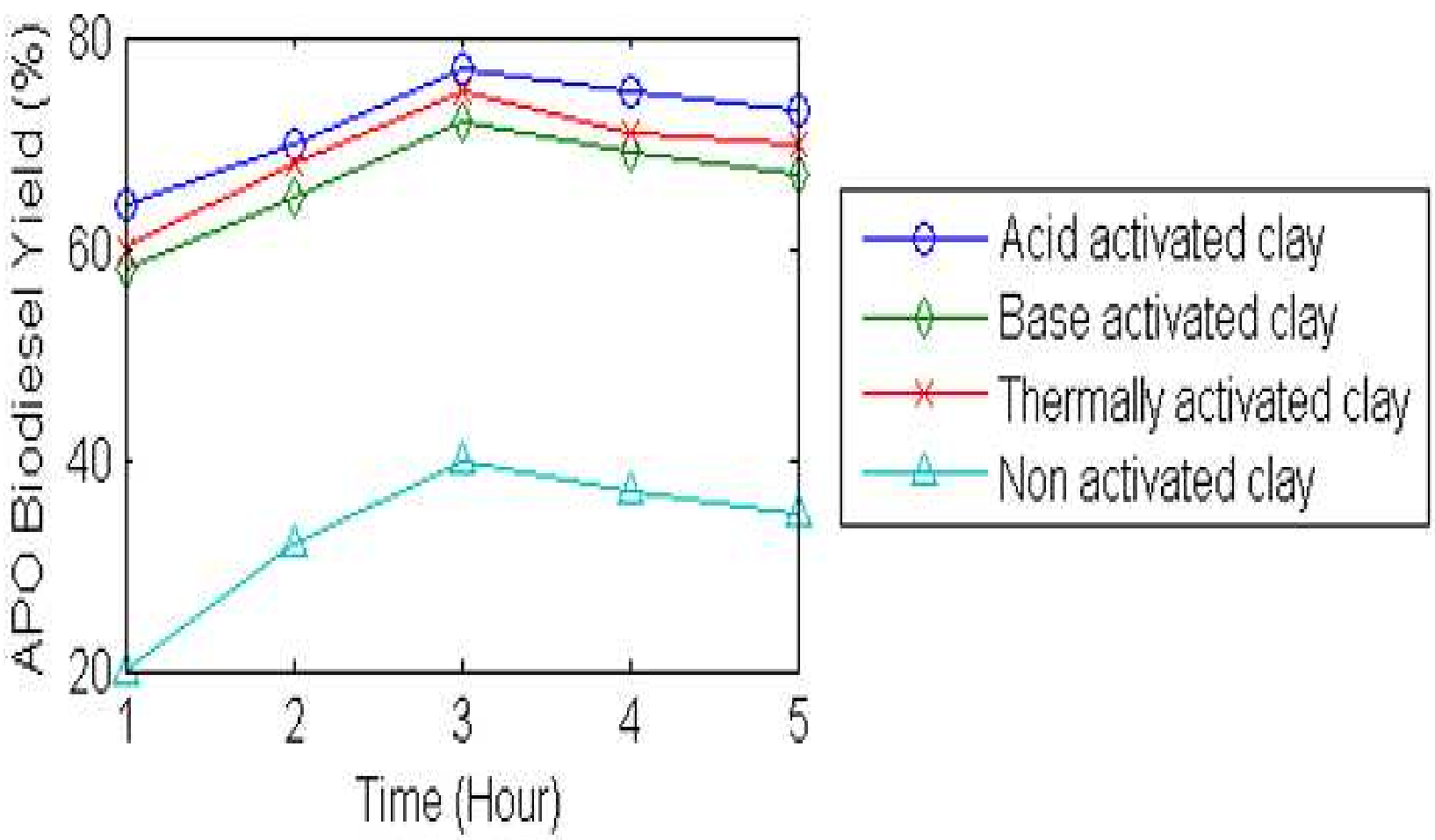

Fig. 3 Influence of time on yield at constant reaction temp. $=55^{\circ} \mathrm{C}$, catalyst conc. $=4 \mathrm{wt} \%$, molar ratio $=12: 1$, agitation speed $=400 \mathrm{rpm}$

\subsubsection{Influence of catalyst concentration on yield}

Activation energy is surmounted before a chemical reaction takes place. This may take too long but an alternative pathway can be provide using catalyst. Raw clay, thermally activated clay, acid activated clay and base/alkaline activated clay catalysts were employed as heterogeneous catalysts for the reaction. The influence of catalysts concentration in terms of oil weight on the biodiesel yield is shown in Figure 4. The figure shows that biodiesel yield increased as catalyst concentration increases till $3 \mathrm{wt} \%$ and then began to decrease. This may be due to inhibition of product formation caused by dispersion and mixing problems associated with excess catalyst (Onukwuli et al. 2019b). 

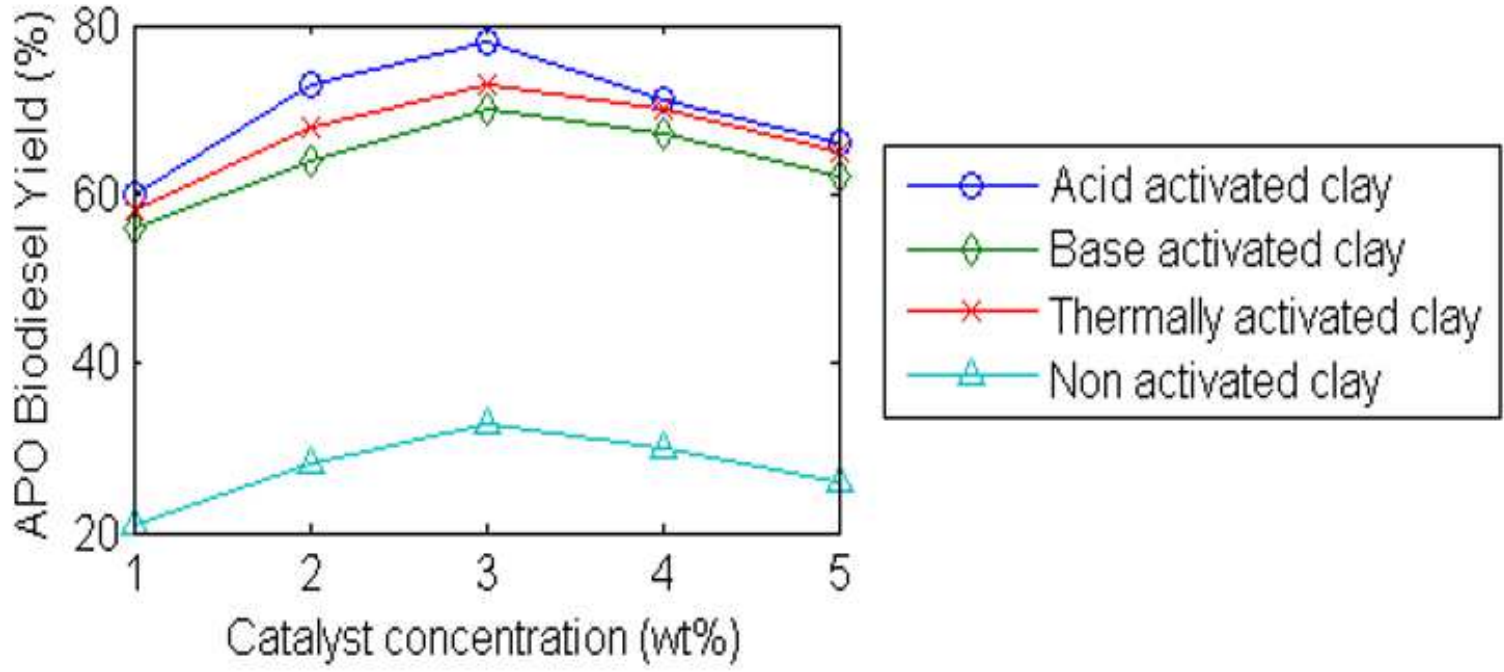

Fig. 4 Influence of catalyst conc. on yield at constant reaction temp. $=55^{\circ} \mathrm{C}$, molar ratio $=12: 1$, agitation speed $=400$ rpm, reaction time $=3 \mathrm{~h}$

\subsubsection{Influence of methanol/oil molar ratio on yield}

The influence of alcohol to oil molar ratio on the yield of biodiesel produced during transesterification of APO catalysed by raw clay, thermally activated clay, acid activated clay and base/alkaline activated clay catalysts is shown in Figure 5. The alcohol used is methanol and its ratio with APO was varied from 6:1 to 14:1. Figure 5 shows that methanol/oil ratio significantly affect the yield of biodiesel and similar trend was observed for the reactions catalysed by the catalysts. The yield increased with methanol/oil ratio to a maximum molar ratio of 10:1 and then decreased beyond the maximum point. This may be attributed to reduction in catalyst activity and difficulty in separation of glycerol as a result of emulsification caused by higher molar ratio (Leung and Guo 2006; Onukwuli and Ude, 2019a). The acid catalysed transesterification reaction produced highest yield due to its high surface area.

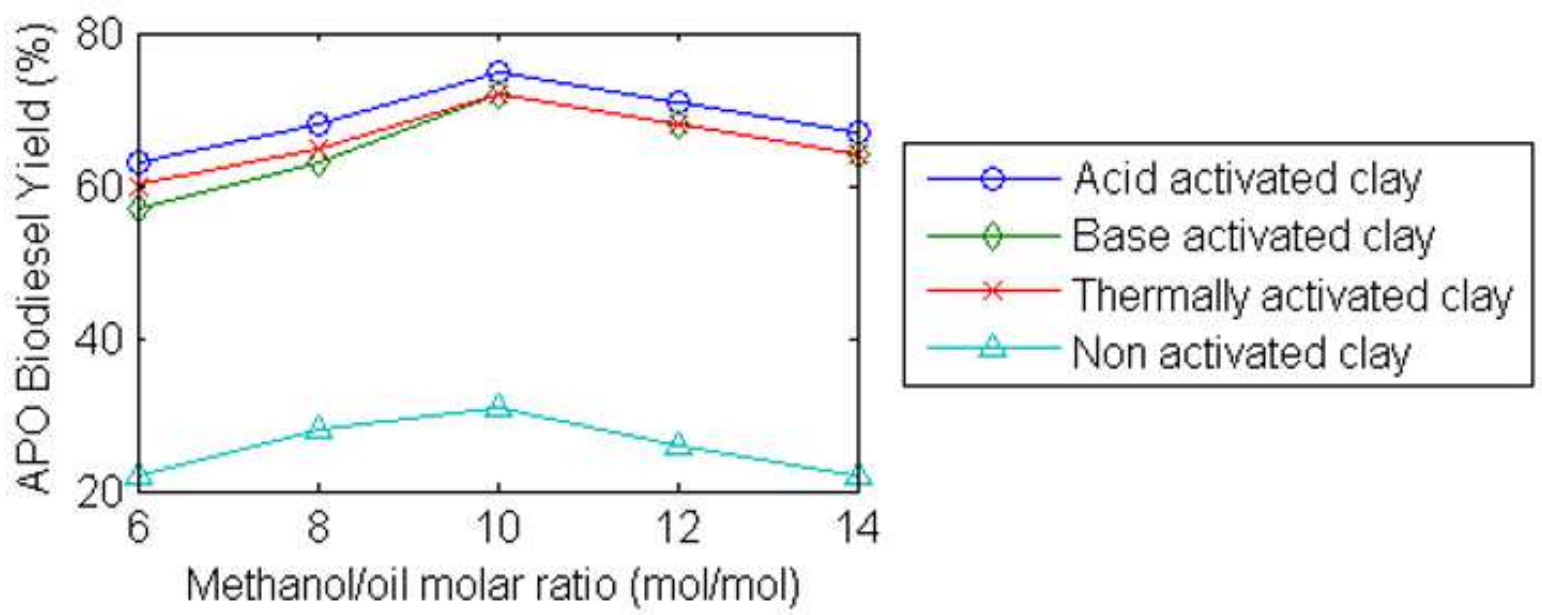


Fig. 5 Influence of methanol/oil molar ratio on yield at constant reaction temp. $=55^{\circ} \mathrm{C}$, agitation speed $=400 \mathrm{rpm}$, reaction time $=3 \mathrm{~h}$, catalyst conc. $=3 \mathrm{wt} \%$

\subsubsection{Influence of temperature on yield}

The influence of temperature on the yield of biodiesel produced by transesterification of APO catalysed by raw clay, thermally, acid and alkaline activated clay is presented in Figure 6. The reaction temperature was varied from 45, 50, $55,60,65$ and $70^{\circ} \mathrm{C}$, while the other parameters were kept constant. The yield of biodiesel increases as temperature increased to a maximum yield at a temperature of $60{ }^{\circ} \mathrm{C}$ and decreased beyond that point. At higher temperature above boiling point of methanol, its evaporated and condensed but retarded the rate of formation of biodiesel. Similar result was reported by Liu et al. (2008) and Ude and Onukwuli (2019b).

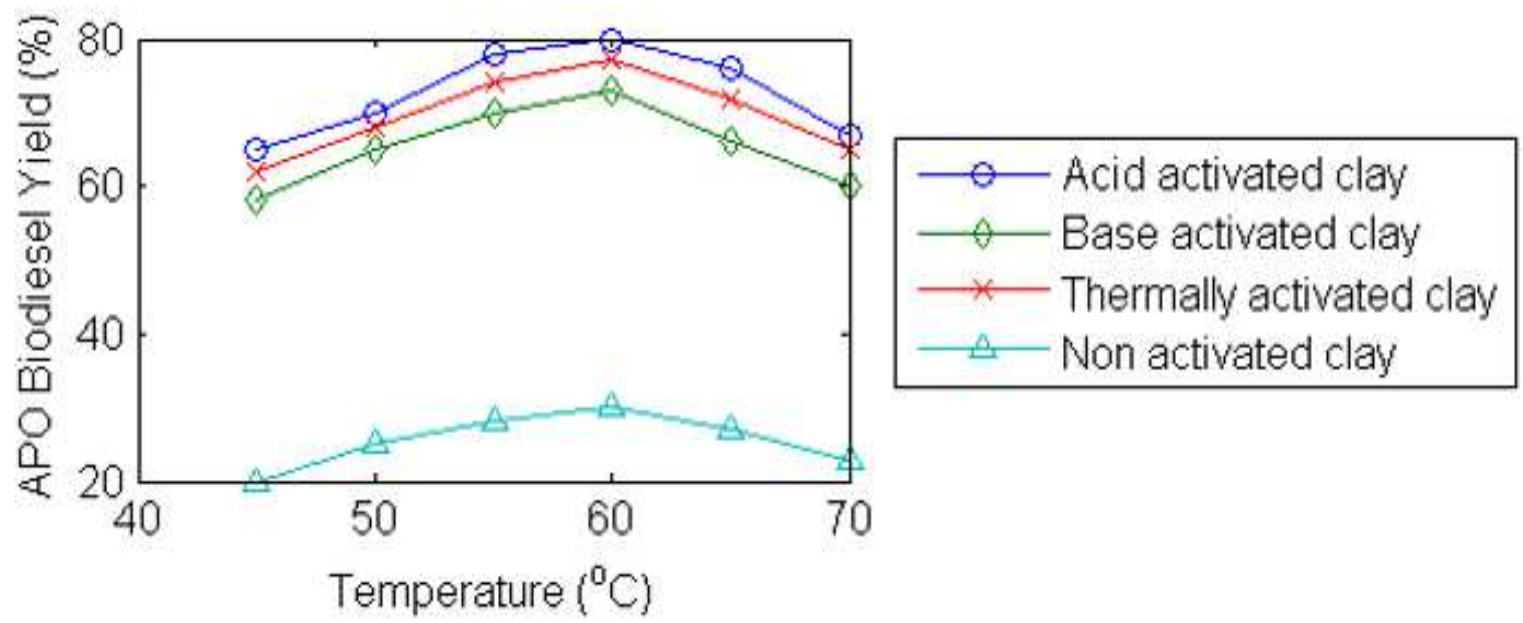

Fig. 6 Influence of temperature on biodiesel yield at constant agitation speed $=400 \mathrm{rpm}$, reaction time $=3 \mathrm{~h}$, catalyst conc. $=3 \mathrm{wt} \%$, methanol/oil molar ratio $=10: 1$

\subsubsection{Influence of agitation speed on yield}

The agitation creates homogeneous mixture of the reactants and enhance reactivity. The influence of agitation speed on biodiesel yield is shown in Figure 7. It was observed that the yield increased as agitation speed increased but gradually decreased beyond $300 \mathrm{rpm}$. Also the yield of biodiesel produced from APO catalysed with the four catalysts exhibit similar trend with acid catalysed transesterification produced highest yield due to more pores and larger surface area. 


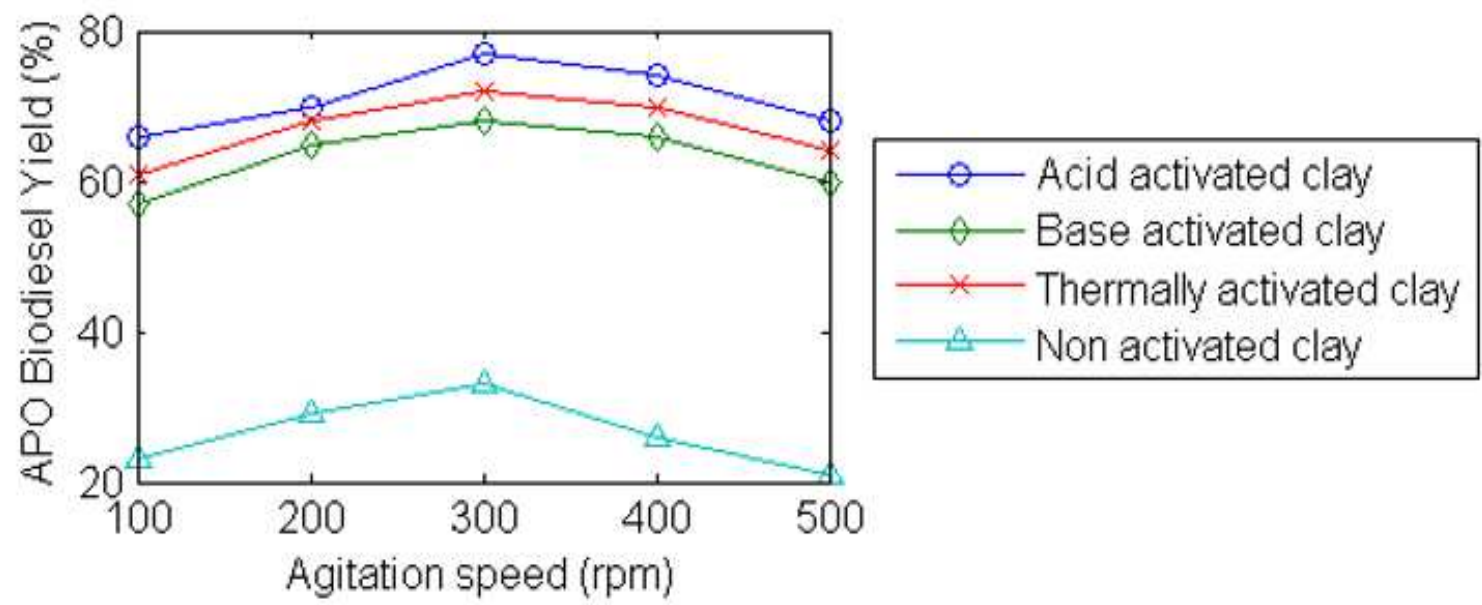

Fig. 7 Influence of agitation speed on biodiesel yield at constant reaction time $=3 \mathrm{~h}$, catalyst conc. $=3 \mathrm{wt} \%$, methanol/oil molar ratio $=10: 1$, temperature $=60{ }^{\circ} \mathrm{C}$

\subsection{Characterization of Biodiesel Produced using maximum Conditions}

The properties of the biodiesel produced using maximum values of process parameters are presented in Table 5 and they were compared with (ASTM D 6751 (2002) standards).

The density of biodiesel produced is higher than petro-diesel. This indicates that biodiesel will be slowly consumed in the combustion chamber. The densities of the APO FAMEs produced by TAC, AAC and BAC catalysts evaluated at $30^{\circ} \mathrm{C}$ were within the ASTM limits for biodiesel (Table 5). Viscosity of neat vegetable oil is always high and they cause serious problems in unmodified engines. This is the most significant change observed in transesterification of vegetable oil. Biodiesel has higher viscosity than petro-diesel due to presence of mono, di or triglycerides. It could be observed from Table 5 that the viscosity of APO FAME fall within the ASTM limits (1.6-6.0 Cst) for biodiesel. This shows that it can be atomized effectively in combustion engine.

The flash point is a determinant for flammability classification of materials. The flash point of the APO FAME is $>170^{\circ} \mathrm{C}$, which falls within the ASTM standard and makes it safe for storage. It has an acid value $<0.5 \mathrm{mgKOH} / \mathrm{g}$ which is within the ASTM value for TAN implying that the acid value of the biodiesel is acceptable. Cetane number is a measure of ignition quality. The cetane number of the APO FAME was $>50$, which is above the lower limit for cetane number indicating that the biodiesel has lower emission of pollutants. The oxidation stability is one of the most important factors used to determine how long an oil/diesel will last in a particular application. From Table 5, it could be observed that the oxidation stabilities of all the biodiesel produced were within the ASTM acceptable limits for biodiesel. This shows that the biodiesel is good for application in a diesel engine but blending it with little diesel it will improve its engine performance. Also the biodiesel produced with catalyst activated in different forms have similar properties and are miscible. 
Table 5: Fuel properties of APO biodiesel compared with ASTM limits.

\begin{tabular}{|c|c|c|c|c|c|}
\hline Properties & Unit & $\begin{array}{l}\text { ASTM } \\
\text { METHODS }\end{array}$ & $\begin{array}{l}\text { APO FAME by } \\
\text { TAC }\end{array}$ & $\begin{array}{l}\text { APO FAME by } \\
\text { AAC }\end{array}$ & $\begin{array}{lll}\text { APO } & \text { FAME by } \\
\text { BAC } & & \end{array}$ \\
\hline Density & $\mathrm{kg} / \mathrm{m}^{3}$ & $\begin{array}{l}\text { ASTM } \\
\text { D-1298 }\end{array}$ & 860 & 858 & 859 \\
\hline Kinematics & Cst & ASTM & 3.6 & 3.7 & 3.8 \\
\hline Viscosity & & D-445 & & & \\
\hline FP & ${ }^{\circ} \mathrm{C}$ & ASTM D-93 & 177 & 180 & 178 \\
\hline PP & ${ }^{\circ} \mathrm{C}$ & $\begin{array}{l}\text { ASTM } \\
\text { D-97 }\end{array}$ & 2 & 3 & 1 \\
\hline $\mathrm{CP}$ & ${ }^{\circ} \mathrm{C}$ & $\begin{array}{l}\text { ASTM } \\
\text { D-2500 }\end{array}$ & 1.3 & 1.4 & 1.4 \\
\hline $\mathrm{AV}$ & $\mathrm{mgKOH} / \mathrm{g}$ & $\begin{array}{l}\text { ASTM } \\
\text { D-974 }\end{array}$ & 0.3 & 0.15 & 0.21 \\
\hline Low Heating Value & $\mathrm{MJ} / \mathrm{kg}$ & & 40.1 & 41 & 41 \\
\hline $\begin{array}{l}\text { Higher Heating } \\
\text { Value }\end{array}$ & $\mathrm{MJ} / \mathrm{Kg}$ & & 51 & 52 & 52 \\
\hline Oxidative stability & Hour & $\begin{array}{l}\text { ASTM } \\
\text { D-6751/EN } \\
14112\end{array}$ & 5.0 & 5.5 & 5.2 \\
\hline Cetane number & & $\begin{array}{l}\text { ASTM } \\
\text { D-130 }\end{array}$ & 52 & 56 & 54 \\
\hline
\end{tabular}

$\mathrm{FP}=$ flash point, $\mathrm{PP}=$ pour point, $\mathrm{CP}=$ cloud point, $\mathrm{AV}=$ acid value

\subsection{Modelling of thermos-physical properties of APO FAME}

\subsubsection{Density Model}

Density of biodiesel from APO was predicted using polymath statistical tools. The empirical relationship between density and fraction of biodiesel is shown in Eq. 7. From the equation, it is observed that density is affected by biodiesel content as their coefficients are very large. The performance parameter results for the linear regressions model is: $\mathrm{R}^{2}$ $=0.995$, RMSE $=0.17$ indicating a good correlation between the input data, as shown in Figure 8. From the figure, it can be observed that density increases with biodiesel content.

$$
\rho_{A P O F A M E}=839.43+18.14 x
$$




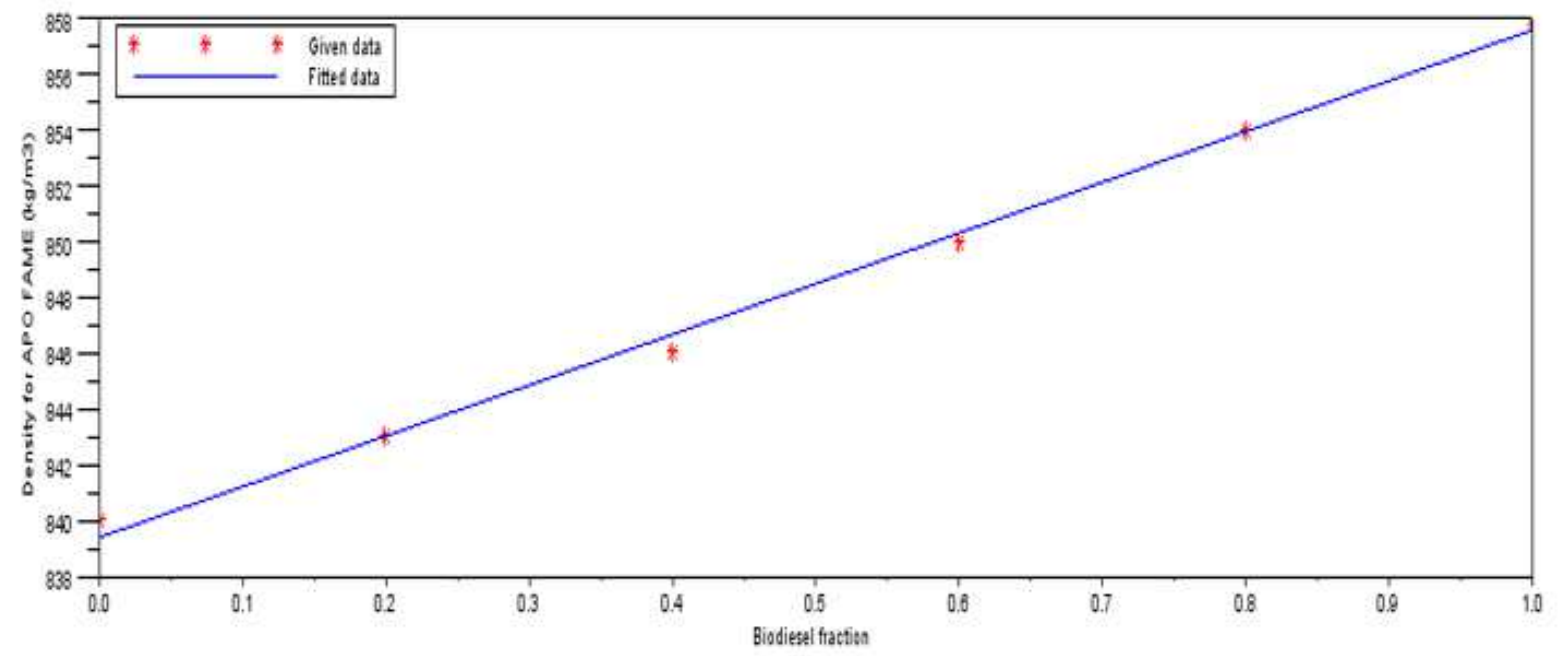

Fig. 8 Plot of density against biodiesel fraction

\subsubsection{Kinematic viscosity model}

Kinematic viscosity of biodiesel from APO was predicted by processing the experimental data using polymath statistical tools. The empirical relationship between kinematic viscosity and fraction of biodiesel with temperature are shown in Eqs. (8 and 9). From the equations, it is observed that kinematic viscosity is affected by biodiesel content and temperature as their coefficients are very large. The performance parameters results for the linear regressions model for kinematic viscosity vs biodiesel fraction are: $\mathrm{R}^{2}=0.97$, RMSE $=0.04$ while the performance parameters results for the linear regressions model for kinematic viscosity vs temperature are: $\mathrm{R}^{2}=0.97$, RMSE $=0.04$ which indicate good correlation between the input data, as shown in Figure 9. It can be observed from the figure that kinematic viscosity increase as biodiesel content increases and decrease as temperature increases. The models are similar and this could be that biodiesel content in the blends did not dominate.

$$
\begin{aligned}
& \gamma_{A P O F A M E}=1.78+1.91 x \\
& \gamma_{A P O F A M E}=25.40-0.072 T
\end{aligned}
$$



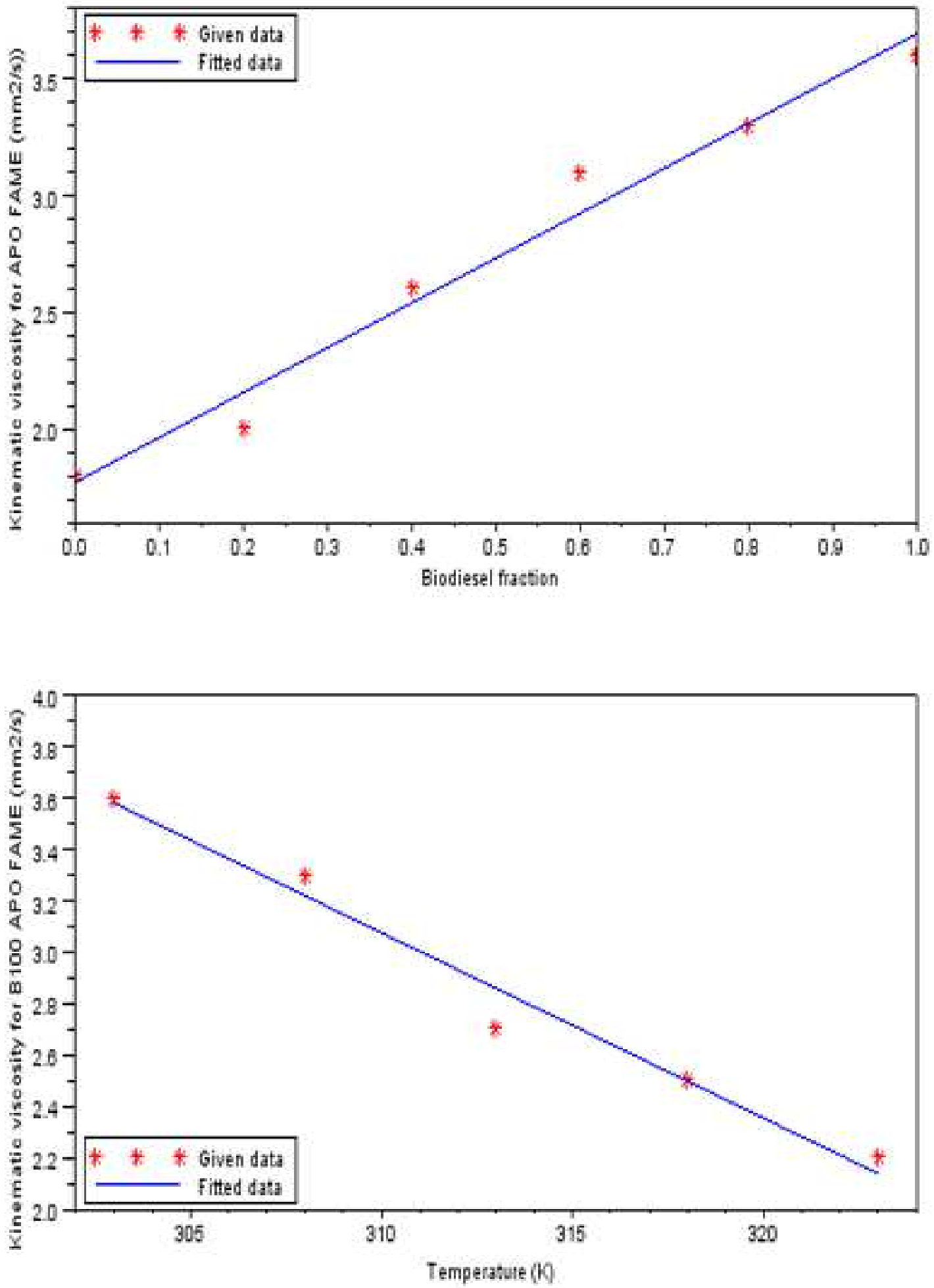

Fig. 9 Kinematic viscosity vs biodiesel fraction and temperature 


\subsubsection{Cetane number model}

The Cetane number of biodiesel was predicted from its thermal properties such as density, kinematic viscosity, flash point and lower heating value using a multiple linear regression MLR model on the experimental data. Equation (15) shows the empirical relationship between Cetane number and thermal properties for APO FAME. From the equation, it is observed that lower heating value (LHV) showed highest influence on the cetane number. Figure 10 shows the subplot of predicted Cetane number values against the experimental data. The figure shows good correlation between the experimental thermal properties and predicted Cetane number. It is also observed from the figures that cetane number increases with increase in density, kinematic viscosity and flash point with decrease in lower heating value. The model performance parameters recorded are: RMSE $=0.035$ and $\mathrm{R}^{2}=0.9995$ (APO FAME) which shows that the empirical correlation proposed can be used to reproduce the Cetane number of biodiesel studied. The predicted equation in terms of the coded values are:

$C N_{A P O F A M E}=3.73 \rho+2.49 \gamma-0.18 \mathrm{FP}+4.30 \mathrm{LHV}-3294.8$
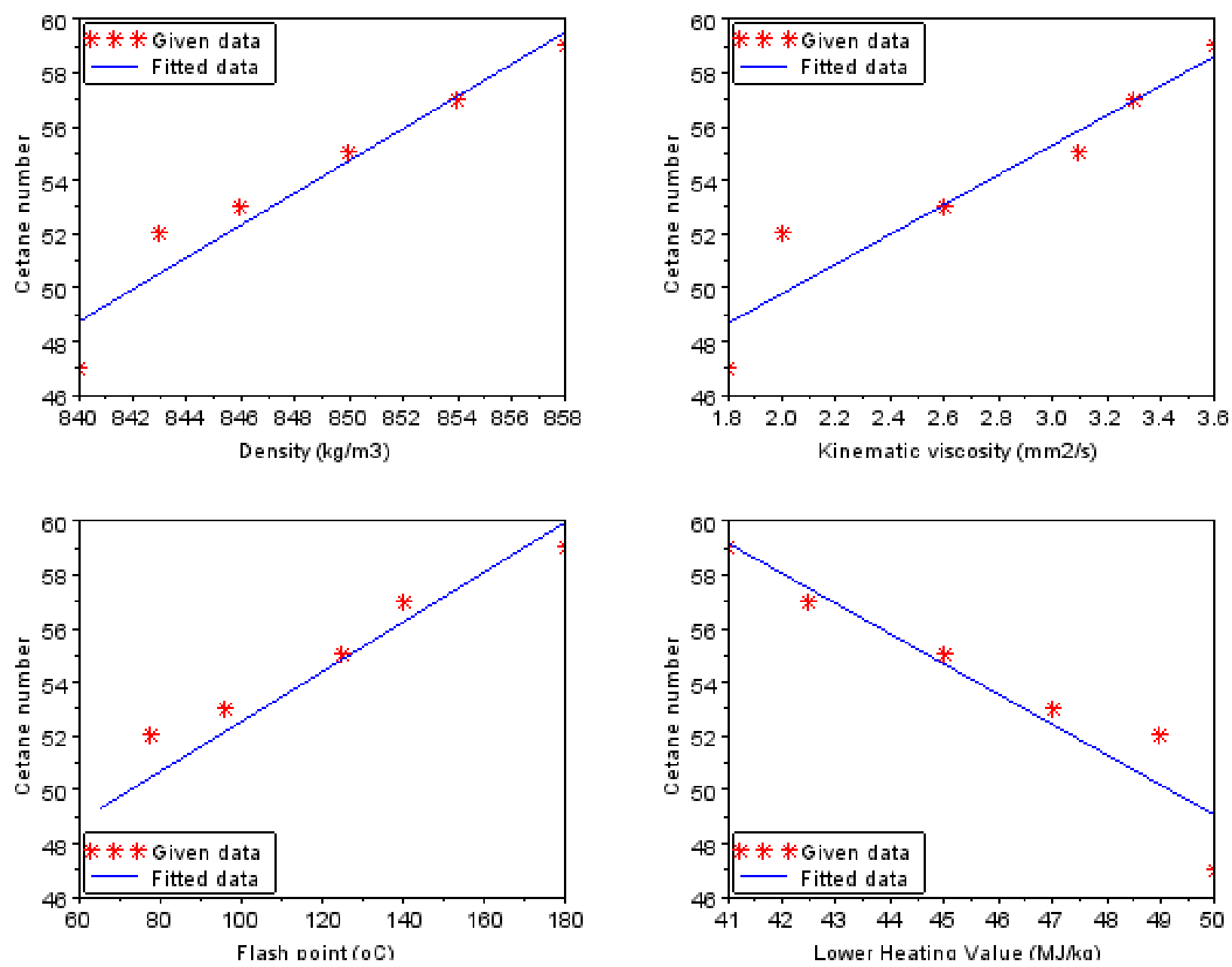

Fig. 10 Cetane number vs thermal properties for APO FAME 


\section{Conclusion}

The yield of oil from the African pear seeds using the petroleum ether was within the quantity of oil obtained by some researchers. The transesterification of the oil was significantly affected by increase in process variables but the yield of methyl ester decreased beyond $3 \mathrm{~h}$ reaction time, $3 \mathrm{wt} \%$ catalyst concentration, 10:1 methanol/oil molar ratio, 60 ${ }^{\circ} \mathrm{C}$ reaction temperature and $300 \mathrm{rpm}$ agitation speed. The physicochemical properties of the biodiesel produced meet the ASTM standard and were within the acceptable limits. The biodiesel produced via transesterification of APO using thermally, acid and alkaline activated catalyst have similar properties and can be blended to form a homogeneous fuel. The linear and multi linear regression were able to predict the thermo-physical properties of the biodiesel with good performance parameters.

\section{Reference}

Adebayo GB, Ameen OM, Abass LT (2011) Physico-chemical properties of biodiesel produced from Jatropha Curcas oil and fossil diesel. Journal of Microbiology and Biotechnology Research 1 (1): 12-16.

AOAC. Official Methods of Analysis (1990) 15th edition, Association of Official Analytical Chemists. Washington DC.

Azam MM, Waris A, Nahar NM (2005) Prospects and potential of fatty acid methyl esters of some non-traditional seed oils for use as biodiesel in India. Biomass Bioenergy 29: 293-302.

Bai R, Shu Wang, Fuming Mei, Tao Li, Guangxing Li (2011) Synthesis of glycerol carbonate from glycerol and dimethyl carbonate catalysed by KF modified hydroxyapatite. Journal of Industrial and Engineering Chemistry 17: 777-781.

Cheng X, Ismail HM, Ng KH, Gan S, Lucchini T (2013) Effects of Fuel Thermo-Physical Properties on Spray Characteristics of Biodiesel Fuels. In Proceedings of the FISITA 2012 World Automotive Congress (pp. 117-126). Springer, Berlin, Heidelberg.

Chhetri AB, Watts KC, Islam MR (2008) Waste cooking oil as an alternate feedstock for biodiesel production. Energies 1(1): 3-18.

Clark JH (2004) Catalysis of organic reaction. VCH, New York.

Hideki F, Akihiko K, Hideo N (2001) Biodiesel fuel production by transesterification of oils. Journal of Bioscience and Bioengineering 92(5): 405-416.

Kim SS, Kim KH, Shin SC, Yim ES (2007) Current Status of Policy and Market for Biodiesel in Korea. Journal of Industrial and Engineering Chemistry 18(5): 401-406.

Lee SB, Han KH, Lee JD, Hong IK (2010) Optimum process and energy density analysis of canola oil biodiesel synthesis. Journal of Industrial and Engineering Chemistry 16: 1006-1010.

Lee SB, Lee JD, Hong IK (2011) Ultrasonic energy effect on vegetable oil based biodiesel synthetic process. Journal of Industrial and Engineering Chemistry 17(1): 138 - 143.

Leung DYC, Guo Y (2006) Transesterification of neat and used frying oil: Optimization for biodiesel production. Fuel Processing Technology 87: 883-890. 
Liu X, He H, Wang Y, Zhu S, Piao X (2008) Transesterification of soybean oil to biodiesel using $\mathrm{CaO}$ as a solid base catalyst. Fuel 87: 216-221.

Manuit J, Statit P (2007) Biodiesel synthesis from transesterification by clay-based catalyst. Chiang Mai Journal Science 34(2): 201-207.

Ofoefule AU, Ibeto CN, Okoro UC, Onukwuli OD (2013) Biodiesel production from tigernut (Cyperus esculentus) oil and characterization of its blend with petro-diesel. Physical Review and Research International 3(2): 145 - 153.

Ogunsuyi HO, Daramola BM (2013) Evaluation of almond seed oil as viable feedstock for biodiesel fuel. International Journal of Biotechnology Resources 1(8): 120-127.

Oh KK, Kim YS, Yoon HH, Tae BS (2002) Pretreatment of lignocellulosic biomass using combination of ammonia recycled percolation and diluted-acid process. Journal of Industrial and Engineering Chemistry 8 (1): 64-68.

P.C. Okonkwo, A. Mukhtar, (2013). Approach to evalution of solvent extraction of oil from Neem seed. International Journal of Applied Science and Technology, 3(6)85 -104.

Olusegun DS, Oreko BU, Oyejide JO, Idi S, Ojo SIF (2019) Experimental and empirical study of diesel and biodiesel produced from blend of fresh vegetable and waste vegetable oil on density, viscosity, Sulphur content and acid value. Journal of Physics: Conference Series, doi:10.1088/1742-6596/1378/4/042024.

Onukwuli OD, Ude CN (2018) Kinetics of African pear seed oil (APO) methanolysis catalyzed by phosphoric acidactivated kaolin clay. Applied Petrochemical Researchhttps://doi.org/10.1007/s13203-018-0210-0.

M. S. Rahman, M. B. Islam, M. A. Rouf, M. A. Jalil, and M. Z. Haque Extraction of Alkaloids and Oil from Karanja (Pongamia pinnata) Seed. Journal of Scientific Research, 3 (3), (2011), 669-675.

Rashid U, Farooq A, Gerhard K (2009) Evaluation of biodiesel obtained from Cottonseed oil. Fuel Processing Technology 90(9): 1157-1163.

Saeid B, Aroua MK, Abdul Raman A, Sulaiman NMN (2008) Density of palm oil-based methyl ester. Journal of Chemical and Engineering Data 53(3): 877-880.

Sani YM, Daud WMAW, AbdulAziz AR (2014) Activity of solid acid catalysts for biodiesel production: A critical review. Applied Catalysis A: General 470: 140 - 161.

Sanjid A, Masjuki HH, Kalam MA, Rahman SMA, Abedin MJ, Fattah IMR (2015) Characterization and prediction of blend properties and evaluation of engine performance and emission parameters of a CI engine operated with various biodiesel blends. RSC Advanced 5: 13246-13255.

Sharma YC, Singh B (2009) Development of biodiesel: current scenario. Renewable and Sustainable Energy Review 13(6-7): 1646-1651.

Sharma YC, Singh B, Upadhyay SN (2008) Advancements in development and characterization of biodiesel: a review. Fuel 87(12): 2355-2373.

Szulczyk KR, McCarl BA (2010) Market penetration of biodiesel. Renewable and Sustainable Energy Reviews 14(8): 2426-2433.

Ude CN, Onukwuli OD (2019a) Kinetic modeling of transesterification of gmelina seed oil catalyzed by alkaline activated clay (NaOH/clay) catalyst. Reaction, Kinetics, Mechanisms and Catalysis, https://doi.org/10.1007/s11144019-01604-x.

Ude CN, Onukwuli OD (2019b) African pear seed oil methanolysis catalyzed by thermally activated clay. Journal of Engineering and Applied Sciences 15(1): 88 - 98. 
Uma BH, Kim YS (2009) A chance for Korea to advance algal-biodiesel technology Review: Journal of Industrial and Engineering Chemistry 15: 1-7.

Zatta L, Ramos LP, Wypych F (2013) Acid-activated montmorillonites as heterogeneous catalysts for the esterification of lauric acid with methanol. Applied Clay Science 80-81: 236-244. 


\section{Supplementary Files}

This is a list of supplementary files associated with this preprint. Click to download.

- GraphicalAbstractCallyBB.docx 